\title{
Efektivitas Penagihan Pajak Dengan Surat Teguran dan Surat Paksa Terhadap Penerimaan Pajak Pada Kantor Pelayananan Pajak Pratama Palembang llir Timur
}

\author{
Elda $^{1}$, Mursalin $^{2}$ \\ ${ }^{1}$ Fakultas Ekonomi dan Bisnis Universitas PGRI Palembang, eldaputrikarwa@gmail.com \\ ${ }^{2}$ Fakultas Ekonomi dan Bisnis Universitas PGRI Palembang, Mursalin@univpgri-palembang.ac.id
}

\begin{abstract}
This research aims to analyze the level of effectiveness of tax collection with reprimands and coercion letters against tax receipts in tax office at Palembang llir Timur. The method that using in this research is descriptive method. The population and sample are using the number of reprimands and forced letters. The data source in this research is secondary data. Data collection techniques are using documentation and literature study techniques. The data analysis technique is using quantitative descriptive analysis. The results showed that tax collection using a reprimand in tax office at Palembang Ilir Timur Primary from 2016 until 2019, when viewed in terms of sheets classified as effective while in terms of nominal classified as ineffective, whereas tax collection using Forced letters in the Tax Office at Palembang llir Timur Pratama from 2016 until 2019 was also classified as effective in terms of sheets in nominal terms classified as ineffective.
\end{abstract}

Keywords: Warning Letter, Forced Letter, Tax Revenue

\begin{abstract}
ABSTRAK
Penelitian ini bertujuan untuk menganalisis tingkat Efektivitas Penagihan Pajak dengan Surat Teguran dan Surat Paksa Terhadap Penerimaan Pajak Pada Kantor Pelayanan Pajak Pratama Palembang Ilir Timur. Metode yang digunakan dalam penelitian ini adalah metode deskriptif. Populasi dan Sampel yang digunakan adalah Jumlah Surat Teguran dan Surat Paksa. Sumber data dalam Penelitian ini adalah data sekunder.Teknik Pengumpulan data yang digunakan adalah teknik dokumentasi dan studi pustaka. Teknik analisis data yang digunkan adalah analisis deskriptif kuantitatif. Hasil penelitian menunjukan bahwa Penagihan Pajak dengan menggunakan Surat Teguran di Kantor Pelayanan Pajak Pratama Palembang llir Timur pada tahun 2016-2019, jika dilihat dari segi lembar tergolong efektif sedangkan dari segi nominal tergolong tidak efektif, Sedangkan Penagihan Pajak dengan menggunakan Surat Paksa di Kantor Pelayanan Pajak Pratama Palembang llir Timur tahun 20162019 juga tergolong efektif dari segi lembar dalam segi nominal tergolong tidak efektif.
\end{abstract}

Kata Kunci : Surat Teguran, Surat Paksa, Penerimaan Pajak

\section{A. PENDAHULUAN}

Sebagai negara yang sedang berkembang Indonesia sedang giatnya melakukan pembangunan di segala bidang, salah satunya dalam pembangunan nasional. Pembangunan nasional merupakan kegiatan yang dilakukan secara terusmenerus dan berkesinambungan yang memiliki tujuan untuk meningkatkan kesejahteraan rakyat baik secara materil dan spiritual. Salah satu cara untuk mewujudkan peningkatan penerimaan pembangunan tersebut adalah dengan menggali sumber dana yang berasal dari dalam negeri, yakni dari sektor pajak. pajak merupakan sumber utama penerimaan negara.

Peranan pajak secara umum semakin dominan, hal ini terlihat jelas dari Anggaran Pendapatan Belanja Negara (APBN) dimana diketahui bahwa penerimaan pajak yang tertuang didalam APBN merupakan penerimaan pajak dalam negeri yang 
terbesar. Berdasarkan data pokok APBN tahun 2018-2019 Melalui Direktorat Jendral Pajak mengemukakan bahwa dari tahun 2019 target dan realisasi penerimaan negara sebesar 1.577,56 triliun Jumlah ini berasal dari total penerimaan perpajakan sebesar $1.136,17$ triliun atau sekitar $72,02 \%$ dari penerimaan negara secara keseluruhan (http://Pajak.go.id). Melihat hal tersebut itulah mengapa pajak telah menjadi sektor yang sangat penting dalam rangka mensukseskan pembangunan.

Di dalam praktiknya optimalisasi penerimaan pajak masih terbentur pada berbagai kendala seperti ketidakmampuan masyarakat untuk membayar pajak, sampai penghindaran pajak dari masyarakat yang merasa rugi kalau membayar pajak atau dari pihak-pihak yang tidak mempunyai kesadaran untuk membayar pajak yang mengakibatkan tidak dilunasinya utang pajak sebagaimana mestinya. Akibat dari kendala itu mengakibatkan tingginya angka tunggakan pajak yang terus menerus semakin meningkat dan tentu saja akan merugikan bagi negara berkembang seperti indonesia oleh karena itu, pihak fiskus diharapkan lebih memperhatikan dan mengawasi wajib pajak dalam melaksanakan perpajakannya. Saat ini ada dua jenis cara melakukan penagihan pajak yang terbaru yaitu menerbitkan surat teguran dan surat paksa sebagai tindakan penagihan penerimaan pajak. tindakan penagihan merupakan wujud upaya untuk mencairkan tunggakan pajak, namun dalam pelaksanaan penagihan haruslah memperhatikan prinsip keseimbangan antara biaya penagihan dengan penerimaan yang didapatkan karena pelaksanaan penagihan dalam rangka pencairan tunggakan pajak mengeluarkan biaya yag tidak sedikit.

\section{Tabel Target Penerimaan Pajak dan Tunggakan Pajak di KPP Pratama Palembang Ilir Timur tahun 2016-2019 (dalam Rupiah)}

\begin{tabular}{|c|c|c|r|}
\hline Tahun & $\begin{array}{c}\text { Target Penerimaan } \\
\text { Pajak }\end{array}$ & $\begin{array}{c}\text { Realisasi Penerimaan } \\
\text { Pajak }\end{array}$ & Tunggakan Pajak \\
\hline 2016 & 2.034 .930 .049 .123 & 1.814 .559 .381 .155 & 130.530 .042 .341 \\
\hline 2017 & 2.100 .006 .452 .000 & 1.697 .082 .677 .223 & 202.948 .990 .681 \\
\hline 2018 & 2.128 .023 .765 .000 & 1.867 .168 .944 .046 & 240.207 .916 .647 \\
\hline 2019 & 1.011 .054 .744 .000 & 1.071 .754 .312 .800 & 268.674 .426 .231 \\
\hline
\end{tabular}

Sumber: Seksi Penagihan Pajak dan Seksi PDI KPP Pratama Palembang (2020)

Dari data diatas, dapat dilihat bahwa pada tahun 2016 target penerimaan pajak sebesar 2.034.930.049.123 namun hanya terrealisasi sebesar 1.814.559.381.155 dan terjadi tunggakan pajak sebesar 130.530.042.341, sementara di tahun 2017 target penerimaan pajaknya sebesar 2.100.006.452.000 yang terrealisasi sebesar 1.697.082.677.223 dan terjadi kembali tunggakan pajak sebesar 202.948.990.681, kemudian di tahun 2018 target penerimaan pajaknya sebesar 2.128.023.765.000 yang hanya terrealisasi sebesar 1.867.168.944.046 dan terjadi tunggakan pajak sebesar 240.207.916.647, lalu di tahun 2019 target penerimaan pajaknya sebesar 1.011.054.744.000 dan terrealisasi sebesar 1.071.754.312.800 kemudian terjadi kembali tunggakan pajak sebesar 268.674.426.231. 


\section{B. KAJIAN TEORI}

\section{Pengertian Pajak}

Soemitro dalam Resmi (2017:1), pajak adalah iuran rakyat kepada kas negara berdasakan undang-undang (yang dapat dipaksakan) dengan tidak mendapatan jasa timbal-balik (Kontraprestasi) yang langsung dapat ditujukan dan yang digunakan untuk membayar pengeluruan umum.

Undang-Undang Nomor 28 Tahun 2007 pajak adalah kontribusi wajib pajak kepada negara yang terutang oleh orang pribadi atau badan yang bersifat memaksa berdasarkan undang-undang, dengan tidak mendapatkan imbalan secara langsung dan digunakan untuk keperluan negara bagi sebesar-besarnya kemakmuran rakyat.

\section{Fungsi Pajak}

Resmi (2017:3) fungsi pajak terbagi dua,yaitu :

1 Fungsi budgetir (sumber keuangan negara)

Pajak berfungsi sebagai salah satu sumber penerimaan pemerintah untuk membiayai

Pengeluran-pengelurannya.

2 Fungsi regularend (pengatur)

Pajak berfungsi sebagai alat untuk mengatur atau melaksanakan kebijakan pemerintahan dalam bidang sosial dan ekonomi.

\section{Penagihan Pajak}

Mardiasmo (2016:151) mendefinisikan bahwa penagihan pajak adalah serangkaian tindakan agar penanggung pajak melunasi utang pajak dan biaya penagihan pajak dengan menegur atau memperingatkan, melaksanakan penagihan seketika dan sekaligus, memberitahukan Surat Paksa, mengusulkan pencegahan, melaksanakan penyitaan, melaksanakan penyanderaan,menjual barang yang telah disita.

\section{Dasar Penagihan Pajak}

Dalam Undang-undang Nomor 19 tahun 1997 sebagaimana telah diubah dengan Undang-undang Nomor 19 tahun 2000 pasal 18 ayat 1 dasar penagihan pajak terdapat dalam 2 pasal yaitu :

1. Pasal 18 ayat 1 UU KUP menyebutkan dasar penagihan pajak adalah :

a Surat Tagihan Pajak (SPT)

b Surat Ketetapan Pajak Kurang Bayar (SKPKB)

c Surat Ketetapan Pajak Kurang Bayar Tambahan (SKBKBT)

d Surat Keputusan Pembetulan, Surat Keputusan Keberatan, Putus Banding.

2. Pasal 12 Undang-undang PBB menyebutkan dasar penagihan pajak adalah :

a Surat Pemberitahuan Pajak Terutang (SPPT)

b Surat Ketetapan Pajak

c Surat Tagihan Pajak ( SPT) merupakan dasar penagihan pajak

\section{Surat Teguran}

Surat Teguran menurut Undang-Undang Nomor 19 tahun 2000 tentang penagihan pajak dengan Surat Paksa pada pasal 1 ayat 10 berbunyi Surat Teguran, Surat peringatanatau surat lain yang sejenis adalah surat yang diterbitkan oleh pejabat untuk menegur atau memperingatkan kepada Wajib Pajak untuk melunasi utang pajaknya. 


\section{Surat Paksa}

Mardiasmo (2016:153) mendefinisikan Surat Paksa adalah surat perintah membayar utang pajak dan biaya penagihan pajak, surat paksa mempunyai kekuatan eksekutorial dan kedudukan hukum yang sama dengan putusan pengadilan yang telah mempunyai kekuatan hukum tetap.

IAI ( 2018:266) Surat Paksa adalah surat perintah membayar utang pajak dan biaya penagihan pajak.

\section{Penerimaan Pajak}

Berdasarkan Undang-Undang Republik Indonesia dengan Nomor 18 tahun 2016 pasal 1 ayat 3 menyebutkan bahwa penerimaan perpajakan adalah semua penerimaan negara yang terdiri atas pendapatan pajak dalam negeri dan pendapatan pajak perdangangan internasional.

\section{Efektivitas}

Mardiasmo (2017:134) efektivitas adalah ukuran berhasil tidaknya pencapaian tujuan suatu organisasi mencapai tujuannya. Dimana apabila suatu organisasi mencapai tujuan maka organisasi tersebut telah berjalan dengan efektif. Kemudian untuk mengetahui apakah suatu organisasi tersebut dikatakan efektif harus diperlukan suatu indikator sebagai tolak ukur untuk mengetahui tingkat keefektivan suatu objek. Untuk menghitung tingkat/rasio keefektivitasan penerbitan surat teguran dan surat paksa tersebut dapat dirumuskan sebagai berikut :

1. Rasio Efektivitas penagihan dengan Surat Teguran

$$
\text { Efektivitas }=\frac{\text { Jumlah penagihan Surat Teguran yang dibayar }}{\text { Jumlah penagihan Surat Teguran yang diterbitkan }} \times 100 \%
$$

2. Rasio Efektivitas penagihan dengan Surat Paksa

Efektivitas $=\frac{\text { Jumlah penagihan Surat Teguran yang dibayar }}{\text { Jumlah penagihan Surat Teguran yang diterbitkan }} \times 100 \%$

Berdasarkan rumus diatas, maka penulis juga menggunakan rumus yang sama untuk mengukur keefektivitasan penagihan pajak dengan menggunakan Surat Teguran dan Surat Paksa pada Kantor Pelayanan Pajak Pratama Palembang Ilir Timur.

Untuk mengukur keefektivitasan digunakan indikator pengukuran sebagai berikut:

Tabel Klarifikasi Pengukuran Efektivitas

\begin{tabular}{|c|c|}
\hline Persentase & Kriteria \\
\hline$>100 \%$ & Sangat efektif \\
\hline $90-100 \%$ & Efektif \\
\hline $80-90 \%$ & Cukup efektif \\
\hline $60 \%-80 \%$ & Kurang efektif \\
\hline$<60 \%$ & Tidak Efektif \\
\hline
\end{tabular}

Sumber : Depdagri, Kepmendagri No 690.900.327 tahun 1996 


\section{METODE PENELITIAN}

1) Populasi dan Sampel

\section{Populasi}

Menurut Sugiyono (2019:126)populasi adalah wilayah generasi yang terdiri atas objek/subjek yang mempunyai kualitas dan karakteristik tertentu yang ditetapkan oleh peneliti untuk dipelajari dan kemudian ditarik kesimpulannya.

Populasi dalam penelitian ini adalah Jumlah Surat Teguran, Jumlah Surat Paksa dan Jumlah Realisasi Penerimaan Pajak dengan Surat Teguran dan Surat Paksa di Kantor Pelayanan Pajak Pratama Palembang llir Timur.

\section{$>$ Sampel}

Menurut Sugiyono (2019:127)Sampel adalah bagian dari sejumlah karakteristik yang dimiliki oleh populasi tersebut.

Sampel yang digunakan untuk penelitian adalah Jumlah Surat Teguran, Jumlah Surat Paksa dan Jumlah Realisasi Penerimaan Pajak dengan Surat Teguran dan Surat Paksa di Kantor Pelayanan Pajak Pratama Palembang llir Timur dari tahun 2016 sampai dengan 2019.

\section{2) Sumber Data}

Menurut Sugiyono (2019:298) bisa dilihat dari sumber datanya,maka pengumpulan data dapat menggunakan Data Primer dan Data Sekunder .

a. Data Primer adalah sumber data yang langsung memberikan data kepada pengumpul data.

b. Data Sekunder adalah sumber yang tidak langsung memberikan data kepada pengumpulan, misalnya lewat orang lain atau lewat dokumen.

Sumber data yang digunakan dalam penelitian ini adalah data sekunder yang di dapat dari objek penelitian pada Kantor Pelayanan Pajak Pratama Palembang Ilir Timur.

\section{3) Teknik Pengumpulan Data}

Teknik Pengumpulan Data yang penulis gunakan di dalam penelitian ini adalah sebagai berikut :

a. Teknik Dokumentasi

Menurut Sugiyono (2019:314) dokumen merupakan catatan peristiwa yang sudah berlalu. Dokumen bisa berbentuk tulisan, gambaran atau karya-karya monumental dari seseorang. Dalam hal ini dokumentansi yang dimaksud yaitu dokumentasi dengan cara meminta langsung data-data yang diperlukan di dalam penelitian ini.

b. Studi Kepustakaan

Menurut Sugiyono (2016:403) studi pustaka digunakan sebagai landasan teori yang akan digunakan dalam menganalisis kasus. Dasar-dasar studi pustaka diperoleh dari buku,literatur-literatur maupun tulisan-tulisan yang berhubungan dengan penelitian ini. Dari penjelasan di atas penulis mencari sumber data dari jurnal, buku-buku yang berhubungan dengan permasalahan. 


\section{4) Teknik Analisis Data}

Menurut Sugiyono (2017:08) teknik analisis data dalam penelitian dapat dikelompokkan menjadi dua, yaitu

a. Analisis Kualitatif

Analisis kualitatif yaitu suatu metode analisis dengan menggunakan data yang berbentuk kalimat,kata,skema,dan gambar.

b. Analisis Kuantitatif

Analisis kuantitatif yaitu metode analisis dengan menggunakan data berbentuk angka atau data kuantitatif yang diangkat.

Analisis dalam penelitian ini menggunakan analisis deskriptif kuantitatif. Rumus yang digunakan dalam penelitian ini adalah efektivitas. Untuk mengetahui seberapa besar tingkatkeefektivitasan Penagihan Pajak dengan menggunakan Surat Teguran dan Surat Paksa terhadap Penerimaan Pajak adalah sebagai berikut :

Analisis Efektivitas :

1. Rasio Efektivitas penagihan dengan Surat Teguran

Efektivitas $=\frac{\text { Jumlah penagihan Surat Teguran yang dibayar }}{\text { Jumlah penagihan Surat Teguran yang diterbitkan }} \times 100 \%$

2. Rasio Efektivitas penagihan dengan Surat Paksa

Efektivitas $=\frac{\text { Jumlah penagihan Surat Teguran yang dibayar }}{\text { Jumlah penagihan Surat Teguran yang diterbitkan }} \times 100 \%$

D. HASIL PENELITIAN

1) Analisis Efektivitas Penagihan Pajak dengan Surat Teguran Pada Kantor Pelayanan Pajak Pratama Palembang llir Timur.

Tabel Penagihan Pajak dengan Surat Teguran di Kantor Pelayanan Pajak Pratama Palembang Ilir Timur Tahun 2016-2019

\begin{tabular}{|c|r|r|r|r|}
\hline \multirow{2}{*}{ Tahun } & \multirow{2}{*}{ Lembar } & \multirow{2}{*}{ Nilai $(\mathrm{Rp})$} & \multicolumn{2}{|c|}{ Kenaikan/Penurunan } \\
\cline { 4 - 5 } & & & \multicolumn{1}{c|}{ Lembar } & \multicolumn{1}{c|}{ Nilai $(\mathrm{Rp})$} \\
\hline 2016 & 1.023 & $6.054 .488 .503,00$ & - & - \\
\hline 2017 & 1.697 & $8.053 .644 .655,00$ & -674 & -1.999 .156 .152 \\
\hline 2018 & 10.139 & $103.636 .729 .936,00$ & -8.442 & -95.583 .085 .282 \\
\hline 2019 & 13.382 & $47.391 .723 .774,52$ & -3.243 & 56.245 .006 .162 \\
\hline
\end{tabular}

Sumber : Seksi Penagihan KPP Pratama Palembang Ilir Timur (2020)

Penagihan pajak dengan Surat Teguran pada tahun 2016 sebanyak 1.023 lembar dengan nominal sebesar $\mathrm{Rp} 6.054 .488 .503,00$ pada tahun 2017 sebanyak 1.697 lembar dengan nominal sebesar Rp 8.053.644.655,00 pada tahun 2018 sebanyak 10.139 lembar dengan nominal sebesar Rp 103.636.729.936,00 dan pada tahun 2019 sebanyak 13.382 lembar dengan nominal Rp 47.391.723.774,52. Dapat dilihat pada tahun 2017 adanya penurunan dalam jumlah lembar penagihan surat teguran sebanyak 674 lembar dengan nominal -Rp 1.999.156.152, dan pada tahun 
2018 pemberian Surat Teguran mengalami penurunan sabanyak 8.442 lembar dengan nominal -Rp 95.583.085.282, sedangkan pada tahun 2019 terjadi penurunan kembali jumlah lembar nominal sebanyak 3.243 lembar dan dari segi nominalnya mengalami peningkatan sebesar $R p$ 56.245.006.162. dapat dilihat dari jumlah nominal yang ada, penerbitan Surat Teguran di Kantor Pelayanan Pajak Pratama Palembang Ilir Timur Mengalami Peningkatan.

2) Penerimaan Tunggakan Pajak dengan Surat Teguran di Kantor Pelayanan Pajak PratamaPalembang Ilir Timur.

Penerimaan tunggakan pajak merupakan pelunasan utang pajak atau Tunggakan pajak oleh Wajib Pajak /penanggung pajak. Dengan penerimaan tunggakan pajak, penerimaan pajak pada KPP Pratama Palembang Ilir Timur akan mengalami peningkatan,sehingga membantu pencapaian target penerimaan negara yang berasal dari pajak.

\section{Tabel Realisasi Penerimaan Tunggakan Pajak dengan Surat Teguran di Kantor Pelayanan Pajak Pratama Palembang Ilir Timur Tahun 2016-2019}

\begin{tabular}{|c|r|r|r|r|}
\hline \multirow{2}{*}{ Tahun } & \multirow{2}{*}{ Lembar } & \multirow{2}{*}{ Nilai $(\mathrm{Rp})$} & \multicolumn{2}{|c|}{ Kenaikan/Penurunan } \\
\cline { 3 - 5 } & & & \multicolumn{1}{|c|}{ Lembar } & \multicolumn{1}{c|}{ Nilai $(\mathrm{Rp})$} \\
\hline 2016 & 1.023 & $3.535 .246 .268,00$ & - & - \\
\hline 2017 & 1.697 & $7.055 .847 .459,60$ & -674 & -3.520 .601 .192 \\
\hline 2018 & 10.139 & 16.895 .406 .064 .00 & -8.442 & -9.839 .558 .604 \\
\hline 2019 & 13.382 & $14.791 .271 .697,00$ & -3.243 & 2.104 .134 .367 \\
\hline
\end{tabular}

Sumber : Data sekunder yang diolah (2020)

Realisasi penerimaan tunggakan pajak dengan Surat Teguran yang telah tertagih oleh Seksi Penagihan Kantor Pelayanan Pajak Pratama Palembang Ilir Timur mengalami hal yang jumlah lembarnya sama dengan penagihan Surat Teguran dimana pada tahun 2016 sebanyak 1.023 lembar dengan nilai nominal yang tertagih sebesar $\mathrm{Rp}$ 3.535.246.268,00 pada tahun 2017 sebanyak 1.697 lembar dengan nilai nominal $\mathrm{Rp} 7.055 .847 .459,60$ pada tahun 2018 sebanyak 10.139 lembar dengan nilai nominal $\mathrm{Rp}$ 16.895.406.064.00 sedangkan pada tahun 2019

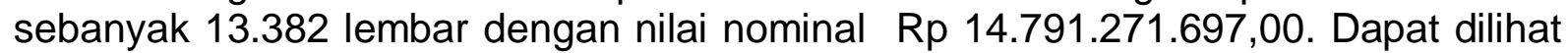
bahwa pada tahun 2017 terjadi penurunan sebanyak 674 lembar Surat Teguran dan nilai nominalnya mengalami penurunan sebesar -Rp 3.520.601.192. pada tahun 2018 terjadinya jumlah lembar Surat Teguran sebanyak 8.442 lembar dan adanya penurunan kembali nilai nominal -Rp 9.839.558.604, sedangkan pada tahun 2019 terjadi penurunan jumlah lembar Surat Teguran sebanyak 3.243 lembar Surat Teguran dan adanya peningkatan penerimaan tunggakan pajak dengan Surat Teguran di Kantor Pelayanan Pajak Pratama Palembang llir Timur SebesarRp 2.104.134.367.

3) Penagihan Pajak dengan Surat Paksa di Kantor Pelayanan Pajak Pratama Palembang llirTimur

Penagihan Pajak dengan Surat Paksa merupakan tindakan penagihan aktif yang dilaksanakan oleh juru sita pajak dengan menyampaikan Surat Paksa kepada Wajib Pajak (WP) untuk melunasi tunggakan pajak dan biaya penagihan lainnya. 


\section{Tabel Penagihan Pajak dengan Surat Paksa di Kantor Pelayanan Pajak Pratama Palembang Ilir Timur} Tahun 2016-2019

\begin{tabular}{|c|r|r|r|r|}
\hline \multirow{2}{*}{ Tahun } & \multirow{2}{*}{ Lembar } & \multirow{2}{*}{ Nilai $(\mathrm{Rp})$} & \multicolumn{2}{|c|}{ Kenaikan/Penurunan } \\
\cline { 4 - 5 } & & & \multicolumn{1}{|c|}{ Lembar } & \multicolumn{1}{c|}{ Nilai $(\mathrm{Rp})$} \\
\hline 2016 & 1.502 & $3.478 .202 .653,00$ & - & - \\
\hline 2017 & 2.047 & $5.252 .346 .093,00$ & -545 & -1.774 .143 .440 \\
\hline 2018 & 2.132 & $13.635 .918 .940,00$ & -85 & -8.383 .572 .847 \\
\hline 2019 & 4.193 & $64.302 .555 .976,70$ & -2.061 & -50.666 .637 .037 \\
\hline
\end{tabular}

Sumber : Seksi Penagihan KPP Pratama Palembang Ilir Timur (2020)

Penagihan pajak dengan Surat Paksa pada tahun 2016 sebanyak 1.502 lembar dengan nilai nominal sebesar $\mathrm{Rp} 3.478 .202 .653,00$ tahun 2017 sebanyak 2.047 lembar dengan nilai nominal sebesar Rp 5.252.346.093,00 tahun 2018 sebanyak 2.132 lembar dengan nilai nominal sebesar $\mathrm{Rp}$ 13.635.918.940,00 sedangkan pada tahun 2019 sebanyak 4.193 lembar dengan nilai nominal sebesar Rp 64.302.555.976,70. Dilihat dari jumlah nominal yang ada penerbitan Surat Paksa di Kantor Pelayanan Pajak Pratama Palembang Ilir Timur mengalami penurunan dari tahun 2016-2019.

4) Penerimaan Tunggakan Pajak dengan Surat Paksa di Kantor Pelayanan Pajak Pratama Palembang Ilir Timur.

Penerimaan Tunggakan Pajak Merupakan pelunasan utang pajak atau Tunggakan pajak oleh Wajib Pajak /penanggung pajak. Dengan penerimaan tunggakan pajak, penerimaan pajak pada KPP Pratama Palembang Ilir Timur akan mengalami peningkatan,sehingga membantu pencapaian target penerimaan negara yang berasal dari pajak.

\section{Tabel Realisasi Penerimaan Tunggakan Pajak dengan Surat Paksa di Kantor Pelayanan Pajak Pratama Palembang Ilir Timur Tahun 2016-2019}

\begin{tabular}{|r|r|r|r|r|}
\hline \multirow{2}{*}{ Tahun } & \multirow{2}{*}{ Lembar } & \multirow{2}{*}{ Nilai $(\mathrm{Rp})$} & \multicolumn{2}{|c|}{ Kenaikan/Penurunan } \\
\cline { 4 - 5 } & & & \multicolumn{1}{|c|}{ Lembar } & \multicolumn{1}{c|}{ Nilai $(\mathrm{Rp})$} \\
\hline 2016 & 1.502 & $1.002 .568 .979,00$ & - & - \\
\hline 2017 & 2.047 & $2.424 .379 .220,00$ & -545 & -1.421 .810 .241 \\
\hline 2018 & 2.132 & $1.948 .288 .762,00$ & -85 & 476.090 .458 \\
\hline 2019 & 4.193 & $3.462 .536 .685,00$ & -2.061 & -1.514 .247 .923 \\
\hline
\end{tabular}

Sumber : Data sekunder yang diolah (2020)

Realisasi penerimaan tunggakan pajak dengan Surat Paksa yang telah tertagih oleh Seksi Penagihan Kantor Pelayanan Pajak Pratama Palembang Ilir Timur mengalami hal yang jumlah lembarnya sama dengan penagihan Surat Paksa dimana pada tahun 2016 sebanyak 1.502 lembar dengan nilai nominal sebesar $\mathrm{Rp}$ 2.424.379.220,00 pada tahun 2017 sebanyak 2.047 lembar dengan nilai nominal sebesar Rp 2.424.379.220,00 dan pada tahun 2018 sebanyak 2.132 lembar dengan nilai nominal sebesar Rp 1.948.288.762,00 sedangkan pada tahun 2019 sebanyak

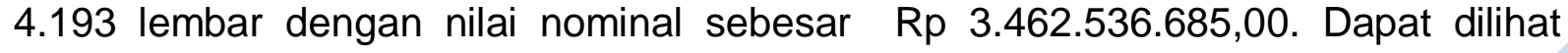


bahwa pada tahun 2017 terjadi penurunan sebanyak 545 lembar Surat Paksa dan nilai nominalnya mengalami penurunan sebesar -Rp 1.421.810.241 pada tahun 2018 terjadinya jumlah lembar Surat Paksa sebanyak 85 dan adanya peningkatan kembali nilai nominal Rp 476.090.458, sedangkan pada tahun 2019 terjadi penurunan jumlah Surat sebanyak 2.061 lembar Surat Paksa dan adanya penurunan penerimaan tunggakan pajak dengan Surat Paksa di Kantor Pelayanan Pajak Pratama Palembang Ilir Timur Sebesar -Rp 1.514.247.923.

\section{E. PEMBAHASAN}

1) Efektivitas Penagihan Pajak dengan Surat Teguran

Efektivitas penagihan pajak dengan Surat Teguran diukur dengan persentase sesuai dengan formula rasio efektivitas yaitu dengan menghitung jumlah penagihan yang dibayar dibagi dengan jumlah yang diterbitkan dikali seratus persen. Perhitungan dilakukan dengan rumus analisis rasio sebagai berikut:

$$
\text { Efektivitas }=\frac{\text { Jumlah Penagihan yang Dibayar }}{\text { Jumlah Penagihan yang Diterbitkan }} \times 100 \%
$$

Perhitungan tingkat efektivitas penerimaan pajak dan pembayaran Surat Teguran di Kantor Pelayanan Pajak Pratama Palembang llir Timur tahun 2016-2019 sebagai berikut :

Efektivitas Tahun $2016($ Nominal $)=\frac{3.535 .246 .268,00}{6.054 .488 .503,00} \times 100 \%=58,39 \%$

Efektivitas Tahun 2016 (Lembar) $=\frac{1203}{1203} \times 100 \%=100 \%$

Tabel Efektivitas Penerimaan Pajak dengan Surat Teguran di Kantor Pelayanan Pajak Pratama Palembang Ilir Timur Tahun 2016

\begin{tabular}{|c|c|c|c|c|c|c|}
\hline \multirow{2}{*}{ Tahun } & \multicolumn{2}{|c|}{ Surat Teguran terbit } & \multicolumn{2}{c|}{ Surat Teguran Bayar } & \multicolumn{2}{c|}{$\begin{array}{c}\text { Tingkat } \\
\text { Efektivitas }\end{array}$} \\
\cline { 2 - 7 } & Lembar & Nominal (Rp) & Lembar & Nominal(Rp) & Lembar & Nominal \\
\hline 2016 & 1.023 & $6.054 .488 .503,00$ & 1.023 & $3.535 .246 .268,00$ & $100 \%$ & $58,39 \%$ \\
\hline
\end{tabular}

Sumber : Data sekunder yang diolah (2020)

Tahun 2016 penerbitan Surat Teguran tercatat sebanyak 1.023 lembar dengan nilai nominal Rp. 6.054.488.503,00 dan realisasi pembayaran oleh Wajib Pajak (WP) sebanyak 1.023 lembar dengan nilai nominal Rp.3.535.246.268,00. Dilihat dari jumlah lembar Surat Teguran memiliki persentase efektivitas $100 \%$ dan dari nominalnya memiliki persentase efektivitas 58,39\%. Berdasarkan kriteria indikator pengukuran efektivitas realisasi penerimaan tunggakan pajak dari penerbitan Surat Teguran pada tahun 2016 dari jumlah lembar Surat teguran tergolong efektif dan jumlah nilai nominal pada tahun 2016 tergolong tidak efektif.

Perhitungan tingkat efektivitas penerimaan pajak dari pembayaran Surat Teguran di Kantor Pelayanan Pajak Pratama Palembang Ilir Timur tahun 2017 sebagai berikut : 
Efektivitas Tahun 2017 (Nominal) $=\frac{7.055 .847 .459,60}{8.053 .644 .655,00} \times 100 \%=87,61 \%$

Efektivitas Tahun 2017 (Lembar ) $=\frac{1697}{1697} \times 100 \%=100 \%$

Tabel Efektivitas Penerimaan Pajak dengan Surat Teguran di Kantor Pelayanan Pajak Pratama Palembang Ilir Timur Tahun 2017

\begin{tabular}{|c|c|c|c|c|c|c|}
\hline \multirow{2}{*}{ Tahun } & \multicolumn{2}{|c|}{ Surat Teguran terbit } & \multicolumn{2}{c|}{ Surat Teguran Bayar } & \multicolumn{2}{c|}{$\begin{array}{c}\text { Tingkat } \\
\text { Efektivitas }\end{array}$} \\
\cline { 2 - 7 } & Lembar & Nominal (Rp) & Lembar & Nominal (Rp) & Lembar & Nominal \\
\hline 2017 & 1.697 & $8.053 .644 .655,00$ & 1.697 & $7.055 .847 .459,60$ & $100 \%$ & $87,61 \%$ \\
\hline
\end{tabular}

Sumber : Data sekunder yang diolah (2020)

Pada tahun 2017 penerbitan Surat Teguran tercatat sebanyak 1.697 lembar dengan nilai nominal Rp. 8.053.644.655,00 dan realisasi pembayaran Tunggakan pajak oleh Wajib Pajak (WP) sebanyak 1.697 lembar dengan nilai nominal Rp.7.055.847.459,60. Dilihat dari jumlah lembar surat memiliki persentase efektivitas $100 \%$ dan dari segi nominalnya memiliki persentase efektivitas $87,61 \%$. Berdasarkan kriteria indikator pengukuran efektivitas realisasi penerimaan tunggakan pajak dari penerbitan Surat Teguran pada tahun 2017 dari jumlah lembar Surat teguran tergolong efektif. Dan nilai nominalnya tergolong cukup efektif.

Perhitungan tingkat efektivitas penerimaan pajak dari pembayaran Surat Teguran di Kantor Pelayanan Pajak Pratama Palembang Ilir Timur tahun 2018 sebagai berikut :

Efektivitas Tahun $2018($ Nominal $)=\frac{16.895 .406 .064,00}{103.636 .729 .936,82} \times 100 \%=16,30 \%$

Efektivitas Tahun 2018 (Lembar ) $=\frac{10139}{10139} \times 100 \%=100 \%$

Tabel Efektivitas Penerimaan Pajak dengan Surat Teguran di Kantor Pelayanan Pajak Pratama Palembang Ilir Timur Tahun 2018

\begin{tabular}{|c|c|l|l|l|l|l|}
\hline \multirow{2}{*}{ Tahun } & \multicolumn{2}{|c|}{ Surat Teguran terbit } & \multicolumn{2}{c|}{ Surat Teguran Bayar } & \multicolumn{2}{c|}{$\begin{array}{c}\text { Tingkat } \\
\text { Efektivitas }\end{array}$} \\
\cline { 2 - 7 } & Lembar & Nominal (Rp) & Lembar & Nominal (Rp) & Lembar & Nominal \\
\hline 2018 & 10.139 & $103.636 .729 .936,82$ & 10.139 & $16.895 .406 .064,00$ & $100 \%$ & $16,30 \%$ \\
\hline
\end{tabular}

Sumber : Data sekunder yang diolah (2020)

Pada tahun 2018 penerbitan Surat Teguran tercatat sebanyak 10.139 lembar dengan nilai nominal Rp. 103.636.729.936,82 dan realisasi pembayaran Tunggakan pajak oleh Wajib Pajak (WP) sebanyak 10.139 lembar dengan nilai nominal Rp. 16.895.406.064,00. Dilihat dari jumlah lembar surat memiliki persentase efektivitas $100 \%$ dan dari segi nominalnya memiliki persentase efektivitas $16,30 \%$. Berdasarkan kriteria indikator pengukuran efektivitas realisasi penerimaan tunggakan pajak dari penerbitan Surat Teguran pada tahun 2018 dari jumlah lembar Surat teguran tergolong efektif. Dan nilai nominalnya tergolong tidak efektif. 
Perhitungan tingkat efektivitas penerimaan pajak dari pembayaran Surat Teguran di Kantor Pelayanan Pajak Pratama Palembang Ilir Timur tahun 2018 sebagai berikut :

Efektivitas Tahun $2019($ Nominal $)=\frac{14.791 .271 .697,00}{47.391 .723 .774,52} \times 100 \%=31,21 \%$

Efektivitas Tahun 2019 (Lembar ) $=\frac{13382}{13382} \times 100 \%=100 \%$

Tabel Efektivitas Penerimaan Pajak dengan Surat Teguran di Kantor Pelayanan Pajak Pratama Palembang Ilir Timur Tahun 2019

\begin{tabular}{|c|c|l|l|l|l|l|}
\hline \multirow{2}{*}{ Tahun } & \multicolumn{2}{|c|}{ Surat Teguran terbit } & \multicolumn{2}{c|}{ Surat Teguran Bayar } & \multicolumn{2}{c|}{$\begin{array}{c}\text { Tingkat } \\
\text { Efektivitas }\end{array}$} \\
\cline { 2 - 7 } & Lembar & Nominal (Rp) & Lembar & Nominal (Rp) & Lembar & Nominal \\
\hline 2019 & 13.382 & $47.391 .723 .774,52$ & 13.382 & $14.791 .271 .697,00$ & $100 \%$ & $31,21 \%$ \\
\hline
\end{tabular}

Sumber : Data sekunder yang diolah (2020).

Pada tahun 2019 penerbitan Surat Teguran tercatat sebanyak lembar 13.382 dengan nilai nominal Rp. 47.391.723.774,42 dan realisasi pembayaran Tunggakan pajak oleh Wajib Pajak (WP) sebanyak 13.382 lembar dengan nilai nominal Rp. 14.791.271.697,00. Dilihat dari jumlah lembar surat memiliki persentase efektivitas $100 \%$ dan dari segi nominalnya memiliki persentase efektivitas $31,21 \%$. Berdasarkan kriteria indikator pengukuran efektivitas realisasi penerimaan tunggakan pajak dari penerbitan Surat Teguran pada tahun 2019 dari jumlah lembar Surat teguran tergolong efektif. Dan nilai nominalnya tergolong tidak efektif.

2) Efektivitas Penagihan Pajak dengan Surat Paksa

Efektivitas penagihan pajak dengan Surat Paksa diukur dengan persentase sesuai dengan formula rasio efektivitas yaitu dengan menghitung jumlah penagihan yang dibayar dibagi dengan jumlah yang diterbitkan dikali seratus persen. Perhitungan dilakukan dengan rumus analisis rasio sebagai berikut :

Efektivitas $=\frac{\text { Jumlah Penagihan yang Dibayar }}{\text { Jumlah Penagihan yang Diterbitkan }} \times 100 \%$

Perhitungan tingkat efektivitas penerimaan pajak dan pembayaran Surat Paksa di Kantor Pelayanan Pajak Pratama Palembang llir Timur tahun 2016-2019 sebagai berikut :

Efektivitas Tahun $2016($ Nominal $)=\frac{1.002 .568 .979,00}{3.478 .202 .653,00} \times 100 \%=28,82 \%$

Efektivitas Tahun 2016 (Lembar) $=\frac{1502}{1502} \times 100 \%=100 \%$ 
Tabel Efektivitas Penerimaan Pajak dengan Surat Paksa di Kantor Pelayanan Pajak Pratama Palembang Ilir TimurTahun 2016

\begin{tabular}{|c|c|l|c|l|c|c|}
\hline \multirow{2}{*}{ Tahun } & \multicolumn{2}{|c|}{ Surat Teguran terbit } & \multicolumn{2}{c|}{ Surat Teguran Bayar } & \multicolumn{2}{c|}{$\begin{array}{c}\text { Tingkat } \\
\text { Efektivitas }\end{array}$} \\
\cline { 2 - 7 } & Lembar & Nominal (Rp) & Lembar & Nominal (Rp) & Lembar & Nominal \\
\hline 2016 & 1.502 & $3.478 .202 .653,00$ & 1.502 & $1.002 .568 .979,00$ & $100 \%$ & $28,82 \%$ \\
\hline
\end{tabular}

Sumber : Data sekunder yang diolah (2020)

Pada tahun 2016 penerbitan Surat Paksa tercatat sebanyak 1.502 lembar dengan nilai nominal Rp. 3.478.202.653,00 dan realisasi pembayaran Tunggakan pajak oleh Wajib Pajak (WP) sebanyak 1.502 lembar dengan nilai nominal Rp. 1.002.568.979,00. Dilihat dari jumlah lembar surat memiliki persentase efektivitas $100 \%$ dan dari segi nominalnya memiliki persentase efektivitas $28,82 \%$. Berdasarkan kriteria indikator pengukuran efektivitas realisasi penerimaan tunggakan pajak dengan Surat Paksa pada tahun 2016 dari jumlah lembar Surat Paksa tergolong efektif. Dan nilai nominalnya tergolong tidak efektif.

Perhitungan tingkat efektivitas penerimaan pajak dan pembayaran Surat Paksa di Kantor Pelayanan Pajak Pratama Palembang Ilir Timur tahun 2017 sebagai berikut :

Efektivitas Tahun 2017 (Nominal) $=\frac{2.424 .379 .220,00}{5.252 .346 .093,00} \times 100 \%=46,15 \%$

Efektivitas Tahun 2017 (Lembar) $=\frac{2047}{2047} \times 100 \%=100 \%$

Tabel Efektivitas Penerimaan Pajak dengan Surat Paksa di Kantor Pelayanan Pajak Pratama Palembang Ilir Timur Tahun 2017

\begin{tabular}{|c|c|l|c|l|c|c|}
\hline \multirow{2}{*}{ Tahun } & \multicolumn{2}{|c|}{ Surat Teguran terbit } & \multicolumn{2}{c|}{ Surat Teguran Bayar } & \multicolumn{2}{c|}{$\begin{array}{c}\text { Tingkat } \\
\text { Efektivitas }\end{array}$} \\
\cline { 2 - 7 } & Lembar & Nominal (Rp) & Lembar & Nominal (Rp) & Lembar & Nominal \\
\hline 2017 & 2.047 & $5.252 .346 .093,00$ & 2.047 & $2.424 .379 .220,00$ & $100 \%$ & $46,15 \%$ \\
\hline
\end{tabular}

Sumber : Data sekunder yang diolah (2020)

Pada tahun 2017 penerbitan Surat Paksa tercatat sebanyak 2.047lembar dengan nilai nominal Rp. 5.252.346.093,00 dan realisasi pembayaran Tunggakan pajak oleh Wajib Pajak (WP) sebanyak 2.047 lembar dengan nilai nominal Rp. 2.424.379.220,00. Dilihat dari jumlah lembar surat memiliki persentase efektivitas $100 \%$ dan dari segi nominalnya memiliki persentase efektivitas $46,15 \%$. Berdasarkan kriteria indikator pengukuran efektivitas realisasi penerimaan tunggakan pajak dengan Surat Paksa pada tahun 2016 dari jumlah lembar Surat Paksa tergolong efektif. Dan nilai nominalnya tergolong tidak efektif.

Perhitungan tingkat efektivitas penerimaan pajak dan pembayaran Surat Paksa di Kantor Pelayanan Pajak Pratama Palembang Ilir Timur tahun 2018 sebagai berikut : 
Efektivitas Tahun 2018 (Nominal) $=\frac{1.948 .288 .762,00}{13.635 .918 .940,00} x 100 \%=14,28 \%$

Efektivitas Tahun 2018 (Lembar) $=\frac{2132}{2132} \times 100 \%=100 \%$

Tabel Efektivitas Penerimaan Pajak dengan Surat Paksa

di Kantor Pelayanan Pajak Pratama Palembang Ilir Timur Tahun 2018

\begin{tabular}{|c|c|l|l|l|l|l|}
\hline \multirow{2}{*}{ Tahun } & \multicolumn{2}{|c|}{ Surat Teguran terbit } & \multicolumn{2}{c|}{ Surat Teguran Bayar } & \multicolumn{2}{c|}{$\begin{array}{c}\text { Tingkat } \\
\text { Efektivitas }\end{array}$} \\
\cline { 2 - 7 } & Lembar & Nominal (Rp) & Lembar & Nominal (Rp) & Lembar & Nominal \\
\hline 2018 & 2.132 & $13.635 .918 .940,00$ & 2.132 & $1.948 .288 .762,00$ & $100 \%$ & $14,28 \%$ \\
\hline
\end{tabular}

Sumber : Data sekunder yang diolah (2020)

Pada tahun 2018 penerbitan Surat Paksa tercatat sebanyak 2.132 lembar dengan nilai nominal Rp. 13.635.918.940,00 dan realisasi pembayaran Tunggakan pajak oleh Wajib Pajak (WP) sebanyak 2.132 lembar dengan nilai nominal Rp. 1.948.288.762,00 Dilihat dari jumlah lembar surat memiliki persentase efektivitas $100 \%$ dan dari segi nominalnya memiliki persentase efektivitas $14,28 \%$. Berdasarkan kriteria indikator pengukuran efektivitas realisasi penerimaan tunggakan pajak dengan Surat Paksa pada tahun 2018 dari jumlah lembar Surat Paksa tergolong efektif. Dan nilai nominalnya tergolong tidak efektif.

Perhitungan tingkat efektivitas penerimaan pajak dan pembayaran Surat Paksa di Kantor Pelayanan Pajak Pratama Palembang Ilir Timur tahun 2019 sebagai berikut:

Efektivitas Tahun 2019 (Nominal) $=\frac{3.462 .536 .685,00}{64.302 .555 .976,00} \times 100 \%=5,38 \%$

Efektivitas Tahun $2019($ Lembar $)=\frac{4193}{4193} \times 100 \%=100 \%$

Tabel Efektivitas Penerimaan Pajak dengan Surat Paksa di Kantor Pelayanan Pajak Pratama Palembang Ilir Timur Tahun 2019

\begin{tabular}{|c|c|l|c|l|c|c|}
\hline \multirow{2}{*}{ Tahun } & \multicolumn{2}{|c|}{ Surat Teguran terbit } & \multicolumn{2}{c|}{ Surat Teguran Bayar } & \multicolumn{2}{c|}{$\begin{array}{c}\text { Tingkat } \\
\text { Efektivitas }\end{array}$} \\
\cline { 2 - 7 } & Lembar & Nominal (Rp) & Lembar & Nominal (Rp) & Lembar & Nominal \\
\hline 2019 & 4.193 & $64.302 .555 .976,00$ & 4.193 & $3.462 .536 .685,00$ & $100 \%$ & $5,38 \%$ \\
\hline
\end{tabular}

Sumber : Data sekunder yang diolah (2020)

Pada tahun 2019 penerbitan Surat Paksa tercatat sebanyak 4.193lembar dengan nilai nominal Rp. 64.302.555.976,00 dan realisasi pembayaran Tunggakan pajak oleh Wajib Pajak (WP) sebanyak 4.193 lembar dengan nilai nominal Rp. 3.462.536.685,00 Dilihat dari jumlah lembar surat memiliki persentase efektivitas $100 \%$ dan dari segi nominalnya memiliki persentase efektivitas 5,38 \%. Berdasarkan kriteria indikator pengukuran efektivitas realisasi penerimaan tunggakan pajak dengan Surat Paksa pada tahun 2019 dari jumlah lembar Surat Paksa tergolong efektif. Dan nilai nominalnya tergolong tidak efektif. 


\section{F. KESIMPULAN DAN SARAN}

1) Kesimpulan

Berdasarkan hasil penelitian dan pembahasan mengenai Efektivitas Penagihan Pajak dengan Surat Teguran dan Surat Paksa terhadap Penerimaan Pajak di Kantor Pelayanan Pajak Pratama Palembang llir Timur, dapat disimpulkan sebagai berikut:

a. Penagihan Pajak dengan menggunakan Surat Teguran di Kantor Pelayanan Pajak (KPP) Pratama Palembang llir Timur pada tahun 2016 sampai dengan 2019 jika dilihat dari segi lembar surat tergolong efektif sedangkan dari segi nominal tergolong tidak efektif.

b. Penagihan Pajak dengan menggunakan Surat Paksa di Kantor Pelayanan pajak (KPP) Pratama Palembang Ilir Timur sama halnya dengan Surat Teguran dimana pada tahun 2016 sampai dengan 2019 jika dilihat dari segi lembar surat tergolong efektif sedangkan dari segi nominal tergolong tidak efektif.

2) Saran

Berdasarkan kesimpulan, penulis memberikan saran kepada Kantor Pelayanan

Pajak (KPP) Pratama Palembang Ilir Timur sebagai berikut:

a. Kantor Pelayanan Pajak Pratama Palembang llir Timur sebaiknya perlu melaksanakan kegiatan penyuluhan tentang perpajakan yang lebih efektif dan efisien untuk mensosialisasikan perundang-undangan yang tertera dalam Undang-Undang Nomor 19 tahun 2000 tentang Penagihan Pajak dengan Surat Paksa kepada masyarakat agar masyarakat benar-benar mengerti dan dapat meningkatkan kesadaran Wajib Pajak dalam membayar pajak. Contohnya dengan cara membuat video pendek tentang Surat Teguran dan Surat Paksa yang diperankan oleh beberapa selebgram palembang dan kemudian disebarluaskan melalui media sosial yang dimiliki oleh Kantor Pelayanan Pajak Pratama Palembang Ilir Timur

b. Kantor Pelayanan Pajak Pratama Palembang llir Timur sebaiknya dapat bekerja sama dengan pemerintahan daerah setempat dalam rangka meningkatkan efektivitas tindakan penagihan pajak dengan Surat Paksa khususnya dalam menelusuri keberadaan Wajib Pajak dan penanggung pajak.

\section{DAFTAR PUSTAKA}

IAI. (2018). Modul Pelatihan Pajak Terapan Brevet AB Terpadu Cetakan 34. Jakarta: Ikatan Akuntan Indonesia.

Kardianti, Earlistiani, dkk. (2017). Efektivitas Penagihan Pajak dengan Surat Teguran dan Surat Paksa terhadap Penerimaan Pajak pada Kantor Pelayanan Pajak Pratama Kuala Tungkal. Jurnal IImiah Ekonomi Global Masa Kini Vol. 8 No.02 Juli 2017.

Madjid, Olvi. dkk. (2015). Efektivitas Penagihan Pajak dengan Surat Teguran dan Surat Paksa terhadap Penerimaan Pajak Pengahasilan pada Kantor Pelayanan Pajak Pratama Bitung. Jurnal EMBA Vol. 3 No. 4 Desember 2015. Hal.478-487.

Mardiasmo.(2016). Perpajakan. Edisi Terbaru.Penerbit: CV ANDI. Yogyakarta. 
Menteri Keuangan RI. (2008). Peraturan Menteri Keuangan No. 85/PMK.03/2008 Tahun 2008 tentang Perubahan Atas Peraturan Menteri Keuangan Nomor 24/PMK.03/2008 tentang Tata cara Pelaksanaan dengan Surat Paksa dan Pelaksanan Penagihan Seketika dan Sekaligus.

Menteri Keuangan RI. (2000). Peraturan Menteri Keuangan No.561/KMK.04/2000 Tahun 2000 tentang Penerbitan Surat Teguran dan Surat Paksa.

Nalle, Filmon Paul. (2017). Efektivitas Penagihan Pajak dengan Surat Teguran dan Surat Paksa Terhadap Penerimaan Pajak pada Kantor Pelayanan Pajak Pratama Singaraja. E-Jurnal Akuntansi Universitas Udayana Vol.20.2. Agustus 2017.

Resmi, Siti. (2017). Perpajakan Teori dan Kasus. Jakarta: Salemba Empat

Republik Indonesia. (2009). Undang-Undang Nomor 16 Tahun 2009 tentang Perubahan Keempat atas Undang Undang Nomor 6 Tahun 1983 tentang Ketentuan Umum dan Tata Cara Perpajakan.

Republik Indonesia. (2007). Undang-Undang Nomor 28 Tahun 2007 tentang Perubahan Ketiga atas Undang-Undang Nomor 6 Tahun 1983 tentang Ketentuan Umum dan Tata Cara Perpajakan Ketentuan Umum dan Tata Cara Perpajakan.

Republik Indonesia. (2008). Undang-Undang Republik Indonesia Nomor 36 Tahun 2008 tentang Perubahan Keempat atas Undang-Undang Nomor 6 Tahun 1983 tentang Pajak Penghasilan.

Republik Indonesia. (2000). Undang-Undang Nomor 19 tahun 2000 tentang Perubahan atas Undang-Undang Republik Indonesia Nomor 19 tahun 1997 tentang Penagihan Surat Paksa.

Republik Indonesia. (2016). Undang-Undang Nomor 18 tahun 2016 tentang Anggaran Pendapatan dan Belanja Negara.

Sugiyono. (2019). Metode Penelitian Kuantitatif dan Kualitatif dan R\&D.: Alfabeta.Bandung. 